\title{
Slaveries and new slaveries: Which role for human dignity?
}

\author{
Pasquale De Sena*
}

\section{Opening remarks}

No one could seriously doubt that respect for dignity is closely connected to the banning of slavery, as well as the banning of torture and human and degrading treatments. In spite of this, such a conclusion is less trivial than it may appear.

In fact, no reference to dignity is made either by the 1926 Convention on Slavery ${ }^{1}$ (at variance with the preamble of the so-called 1956 Supplementary Convention ${ }^{2}$ ), or by the 1930 Convention on the Elimination of Forced Labour. ${ }^{3}$

Dignity made its appearance in the 1948 Universal Declaration of Human Rights (UDHR), ${ }^{4}$ albeit not being provided with a precise definition, as a consequence of two basic circumstances. Indeed, it was clearly perceived that crimes committed by Nazis amounted precisely to an extreme denial of human dignity, and invoking dignity was therefore

* Full Professor of International Law, Catholic University of Milan.

1 'Slavery Convention', signed at Geneva on 25 September 1926 <www.un.org/en/ genocideprevention/documents/atrocity-crimes/Doc.13_slavery\%20conv.pdf>.

2 'Supplementary Convention on the Abolition of Slavery, the Slave Trade, and Institutions and Practices Similar to Slavery', adopted by a Conference of Plenipotentiaries convened by Economic and Social Council resolution 608(XXI) of 30 April 1956 and done at Geneva on 7 September 1956 <www.ohchr.org/Documents/Professional Interest/slaverytrade.pdf>.

3 'Convention concerning Forced or Compulsory Labour' ('Forced Labour Convention', 1930 (No 29)) adopted on 28 June $1930<$ www.ilo.org/dyn/normlex/ en/f?p=NORMLEXPUB:12100:0::NO::P12100_ILO_CODE:C029>.

${ }^{4}$ References to dignity appear: a) in the Preamble of the UDHR (dignity is considered both as the '[...] foundation of freedom, justice and peace in the world [...]' and the object of a common 'faith' of the 'peoples of the United Nations', b) in art 1, according to which 'all human beings are born free and equal in dignity and rights'; c) in two other articles (art 22, right to social security; art 23, para 3, right to work). 
considered as the most appropriate reaction to such denial. ${ }^{5}$ Furthermore, it was precisely the fact that dignity was not provided with a specific legal meaning both in the United Nations Charter and in the Declaration that rendered it able to reconcile different political stances. ${ }^{6}$

Reflecting on the role of dignity with respect to slavery and new slaveries requires, first of all, that a very brief reflection is carried out on the legal meaning of the notion at stake in general terms. On this basis, some remarks will be developed with specific regard to the role played by dignity concerning new slaveries. It is worth noting right now that such a role is far from being insignificant.

2. Legal meanings of dignity: the idea of dignity as a minimum standard of treatment ...

Of course, it is not even possible to sketch here a global discussion on the legal meaning and the legal status of dignity in international law. ${ }^{7}$

5 J Morsink, 'World War Two and the Universal Declaration' (1993) 15 Human Rights Quarterly 357 ff, 362.

6 Such a circumstance is stressed by C McCrudden, 'Human Dignity and Judicial Interpretation of Human Rights' (2008) 19 European J Intl L 655 ff, 678.

${ }^{7}$ To tell the truth, the above aspects are usually not dealt with by international law scholars, apart from C Le Bris L'bumanité saisie par le droit international public (LGDJ 2012) 101 ff, JA Frowein, 'Human Dignity in International Law' in D Kretzmer, E Klein (eds), The Concept of Human Dignity in Human Right Discourse (Kluwer Law International 2002) $121 \mathrm{ff}, \mathrm{K}$ Dicke, 'The Founding Function of Human Dignity in the Universal Declaration of Human Rights' ibid $111 \mathrm{ff}$, O Schachter, 'Human Dignity as a Normative Concept' (1983) 77 AJIL 848 ff and A Verdross, 'La dignité de la personne humaine, base des Droits de l'Homme' (1980) 31 Österreichische Zeitschrift für öffentliches Recht und Völkerrecht 271 ff; dignity is normally investigated by constitutional law scholars (A Barak, Human Dignity. The Constitutional Value and the Constitutional Right, Cambridge (CUP 2015); C Dupré, The Age of Dignity. Human Rights and Constitutionalism in Europe (Hart 2015), S Hennette Vauchez, 'A Human dignitas? Remnants of the Ancient Legal Concept in Contemporary Dignity Jurisprudence' (2011) 9 Intl J Constitutional L 32 ff, S Hennette Vauchez, 'Une dignitas humaine? Vieilles outres, vin nouveau' (2008) 48 Droits 59 ff), human rights judges (JP Costa, 'Human Dignity in the Jurisprudence of the European Court of Human Rights' in C McCrudden (ed), Understanding Human Dignity (OUP 2014) 393 ff), legal theorists ( $\mathrm{J}$ Tasioulas, 'Human Dignity and the Foundations of Human Rights', in C McCrudden (ed), Understanding Human Dignity (OUP 2014) 291-313; B De Gaay Fortman, 'Equal Dignity in International Human Rights', in M Düwell, J Braarvig, R Brownsword, D Mieth (eds), The Cambridge Handbook on Human Dignity (CUP 2014) 
A similar attempt would be manifestly pretentious and no significant result could be achieved in this way.

In spite of this, one may easily argue that both international law scholars and legal theorists display a tendency, starting from the UDHR and the UN Charter, to conclude that dignity would be a sort of empty notion under international law. According to Schachter, for example, dignity could be considered as no more than 'an ideal that has not yet been given substantial specific content', and therefore one could simply suggest some '[...] examples of conduct and ideas antithetical to or incompatible with respect for the inherent dignity of the human person'. ${ }^{8}$

More recently, an analogous stance is taken by McCrudden, according to whom dignity would however play three important 'institutional' roles in the framework of the judicial interpretation of human rights ... precisely as a consequence of it not being provided with a definite legal meaning. ${ }^{9}$

First of all, dignity would be able to provide a '[...] language in which courts can indicate the weighting given to particular rights and other values [...]' in the context of a proportionality test. ${ }^{10}$ To be more precise, in Mc Crudden's opinion, '[w] hen a particular right or other value is described as engaging dignity, this indicates that the court considers that considerable (even in some cases overwhelming) weight should be attributed to it'. ${ }^{1}$

Secondly, having recourse to dignity would enable domestic jurisdictions - particularly during the transition to democracy of Eastern European countries - 'to develop [their] own practice of human rights', albeit on the basis of universal principles of international law. ${ }^{12}$

Lastly, dignity would also function 'as a source from which new rights may be derived, and existing rights extended' within the case law concerning human rights. ${ }^{13}$

355-36, J Waldron, Dignity, Rank and Rights, (OUP 2012), C McCrudden, 'Human Dignity in Human Rights Interpretation' (n 6).

${ }^{8}$ Schachter, 'Human Dignity as a Normative Concept' (n 7) 852.

9 McCrudden, 'Human Dignity and Judicial Interpretation of Human Rights' (n 6) 713.

10 ibid 716

${ }^{11}$ ibid.

12 ibid 720

13 ibid 721 
Be that as it may, concluding that dignity is devoid of a definite legal meaning is somewhat misleading. In other words, it seems to me that such a conclusion simply reflects the difficulty of conceptualising the different meanings that dignity is likely to take on in the relevant practice. Among these different meanings, which cannot be dealt with in depth here ${ }^{14}$ the idea according to which respect for dignity implies a minimum standard to be observed for the treatment of individuals (who find themselves) placed under the power of public authorities comes to the fore.

\section{3. ... and its roots}

Such an idea - which entails that States have to secure the effective enjoyment of this standard of treatment, also by avoiding that private individuals may infringe it - has its roots in two circumstances at least.

I refer, first, to common Article 3, para 1, of the four 1949 Geneva Conventions on humanitarian law, applicable to international and noninternational armed conflict. It is well known that this provision, in addition to the bans on 'murder', 'torture' and 'cruel treatments', also prohibits 'humiliating and degrading treatment', by expressly defining the latter as 'outrages upon personal dignity'. ${ }^{15}$ It is therefore manifestly evident that respect for dignity constitutes the rationale of all the above bans. However, what matters most is that these bans, taken as a whole, are precisely aimed at guaranteeing a minimum standard of treatment for individuals in enemy hands, namely under the power of (foreign) public authorities.

As to the second relevant circumstance, suffice it to recall the widespread tendency to consider respect for dignity as the legal ground for both the ban on torture and cruel and degrading treatment and that of

${ }^{14}$ A tentative, comprehensive legal analysis of these meanings is carried out in P De Sena, 'Dignité humaine et droit international' forthcoming in Recueil des Cours de l'Académie de Droit International.

15 ' $[\ldots]$ the following acts are and shall remain prohibited at any time and in any place whatsoever with respect to the above-mentioned persons: a) violence to life and person, in particular murder of all kinds, mutilation, cruel treatment and torture; $b$ ) taking of hostages; c) outrages upon personal dignity, in particular, humiliating and degrading treatment $[\ldots]$ '. 
slavery; ie two bans that are commonly considered as forming part of the hard core ('noyau dur') of international human rights.

Such a tendency clearly emerges from the very fact that it is precisely by having recourse to dignity that both the bans on slavery and compulsory labour, and torture or inhuman and degrading treatments, have been extended to factual hypotheses which are not expressly covered by the corresponding rules. Leaving aside torture and degrading treatment, two judgments of the European Court of Human Rights may be recalled here with respect to slavery and forced and compulsory labour: Siliadin v France ${ }^{16}$ and Rantsev $v$ Russia and Cyprus ${ }^{17}$ In both these judgments, references to respect for dignity were made by the Court in order to trace back forms of servitude or serious exploitation of labour and trafficking of human persons, respectively, to Article 4 of the Convention.

In Siliadin, the case of a domestic servant who worked 15 hours a day, without a day off or pay for several years, came to the fore. Although Articles 225-13 and 225-14 of the French Criminal Code 'make it an offence, respectively, to exploit an individual's labour and to submit him or her to working or living conditions that are incompatible with human dignity', ${ }^{18}$ the Court granted the application, by arguing that respect for human dignity of Ms Siliadin would have required the adoption of specific (legislative) provisions dealing with treatment contrary to Article 4 of the Convention which she complained about. ${ }^{19}$

In Rantsev, the reference to human dignity made by the Strasbourg judges appears to be even clearer and more significant. In that case, the Court was called upon to rule on the extension of the scope of application of Article 4 to trafficking of human beings, and the application was granted precisely on account that ' $\mathrm{t}] \mathrm{h}$ here can be no doubt that trafficking threatens the human dignity and fundamental freedoms of its vic-

16 Siliadin v France, App no 73316/01 (ECtHR, 26 October 2005).

${ }^{17}$ Rantsev v Russia and Cyprus, App no 25965/04 (ECtHR, 7 January 2010).

18 Siliadin (n 16) para 142.

19 ibid paras 143 ff; in other words, the Court held that the French criminal law which was in force at that time did not offer the applicant an effective protection against 'servitude' or, at least, against 'forced and compulsory labour', both of them being considered as violations of dignity. 
tims'.$^{20}$ Subsequently, positive obligations stemming from the said article were held to be violated by both the respondent States. ${ }^{21}$

Furthermore, it is to be added that neither in Siliadin, nor in Rantsev, did the applicants complain of being property stricto sensu of an owner.

4. Dignity as a general principle of law concerning new forms of slavery: Katanga, Kunarac and Trabajadores de la Hacienda Brazil Verde

Having established that dignity refers, inter alia, to a minimum standard of treatment to be guaranteed to individuals placed under the power of public authorities or other private individuals, another question to be dealt with is the legal function to be recognized to such a notion.

Making use of dignity in order to extend the scope of application of the ban at stake also sheds light upon this question. In other words, having recourse to dignity for this purpose means nothing less - and nothing more - than using dignity as a general principle of law. In fact, the gap-filling function, performed by dignity ${ }^{22}$ with specific respect to slavery, undoubtedly constitutes a typical function of general principles of law.

An important confirmation of the foregoing is given by the judgment rendered by a Trial Chamber of the International Criminal Court (ICC) in Katanga ${ }^{23}$ (2014), as well as the well-known judgment of the International Criminal Tribunal for the Former Yugoslavia (ICTY) in $\operatorname{Kunarac}^{24}$ (2001).

${ }^{20}$ Rantsev (n 17) para 282; the above conclusion was reached, regardless of whether 'the treatment about which the applicant complains constitutes 'slavery', 'servitude' or 'forced and compulsory labour.' (ibid).

${ }^{21}$ ibid paras 293, 298, 300 (Cyprus) and paras 303, 306, 309 (Russia).

${ }^{22}$ Understood as a minimum standard of treatment for individuals placed under the power of public authorities or other private individuals.

${ }_{23}$ Situation in the Democratic Republic of the Congo in the Case of the Prosecutor $v$ Germain Katanga (Judgment pursuant to article 74 of the Statute) ICC-01/04-01/07 (7 March 2014).

${ }^{24}$ Prosecutor v Dragoljub Kunarac Radomir Kovac and Zoran Vukovic (Judgment) IT-96-23-T\& IT-96-23/1-T (22 February 2001). 
In both these cases, the question of enslavement came to the fore, and in both of them, enslavement - as it occurred in Rantsev and Sili$\operatorname{adin}^{25}$ - was considered as not implying ownership in the strict sense, namely as 'acquisition' or 'disposal' of persons for monetary or other compensation.

In Katanga, the ICC, starting from the premise that ownership may take many forms, including 'a situation of dependence which entails [the individual's] deprivation of any form of autonomy, ${ }^{26}$ expressly concluded that ' $[t]$ he use of threats, force or other forms of physical or mental coercion, the exaction of forced labour, the exertion of psychological pressure, the victim's vulnerability and the socioeconomic conditions in which the power is exerted may also be taken into account', given 'that the exercise of the right of ownership over someone need not entail a commercial transaction'. ${ }^{27}$

Similar conclusions had already been reached by ICTY in Kunarac at the beginning of 2000s. Suffice it to consider that according to the Tribunal 'the consent or free will of the victim' are often nullified 'by, for example, the threat or use of force or other forms of coercion; the fear of violence, deception or false promises; the abuse of power; the victim's position of vulnerability, detention or captivity, psychological oppression or socio-economic conditions', ${ }^{28}$ although this way of construing the concept of enslavement ends up being broader than the traditional definitions of slavery, slave trade, etc. ${ }^{29}$

That being said, it has also to be pointed out that in these judgments no explicit references are made to dignity in order to extend the notion of enslavement. In spite of this, no one could seriously question that the need to take into account the dignity of victims of the alleged crimes ${ }^{30}$ led the above tribunals to state that enslavement also occurs in case of 'psychological oppression', 'control of movement', 'threat of force', etc.

${ }^{25}$ See above, section 3.

${ }^{26}$ Katanga (n 23) para 975.

27 ibid 976 (italics added); in this affair the Court was called upon to rule on a case of sexual slavery.

${ }^{28}$ Kunarac (n 26) para 543.

29 ibid para 541 (for an in-depth analysis of the legal history of enslavement under international law: paras 515-539).

${ }^{30}$ Understood as the guarantee of a minimum standard of treatment. 
In addition, the above circumstances have also been deemed relevant for enslavement in the judgment Trabajadores de la Hacienda Brazil Verde $v$ Brazi ${ }^{1}$ rendered by the Inter-American Court of Human Rights (IACtHR) in 2016. In this case, the applicants - 85 workers in a privately-owned estate, among whom some children - claimed to be victims of slavery, on account of their working conditions, under Article 6, para 1 of the Convention. ${ }^{32}$ Their application was granted by the Court, precisely by arguing that deception, fraud, control of movement, physical and psychological forms of coercion against vulnerable persons amounted to a 'situation of slavery' ('situación de esclavitud'), ${ }^{33}$ notwithstanding that such a situation did not entail that victims could be considered as being property stricto sensu of an owner, here either. ${ }^{34}$ It is worth noting that the Court did not fail to stress that slavery represents a major violation of dignity, ${ }^{35}$ being able to subsume other violations equally alleged by the applicants. ${ }^{36}$

\section{5. ... and some recent judgments of the European Court of Human Rights}

Further and even more significant confirmation of the role played by dignity as a general principle can also be found in the recent case law of the European Court concerning new forms of slaveries.

In addition to Rantsev, ${ }^{37}$ a very recent judgment rendered by the Court in S.M. $v$ Croatia $^{38}$ is to be pointed out here. In this judgment, a case of forced prostitution - concerning a young Croatian woman,

${ }^{31}$ Inter-American Court of Human Rights, Tabajadores de la Hacienda Brazil Verde $v$ Brazil (IACtHR, 20 October 2016).

32 They were recruited by fraud and deceit, and subsequently subjected to debt bondage; furthermore, their working conditions were inhuman and they were not free to leave the work place.

${ }_{33}$ Tabajadores de la Hacienda Brazil Verde (n 31) para 304.

34 ibid see paras 269-272 for an in-depth analysis of the pertinent case law.

35 ibid para 317: 'Asimismo, la prohibición a no ser sometido a esclavitud juega un papel fundamental en la Convención Americana, por representar una de las violaciones más fundamentales de la dignidad de la persona humana y, concomitantemente, de varios derechos de la Convención.' (italics added).

36 ibid para 306.

${ }^{37}$ See above, section 3.

38 S.M. v Croatia, App no 60561/14 (ECtHR, 19 July 2018). 
forced to prostitute by a former police officer - came to the fore. In spite of its purely domestic character, the crime at stake has been considered as amounting to trafficking and, therefore, as being a violation of Article 4 of the Convention; ${ }^{39}$ subsequently, Croatia was found responsible for not fulfilling procedural obligations stemming from the above provision. ${ }^{40}$ Such a conclusion was reached precisely by deeming trafficking and sexual exploitation violations of human dignity, regardless of whether these treatments constituted 'slavery', 'servitude' or 'forced and compulsory labour', ${ }^{41}$ and regardless of the fact that no ownership over the victim occurred in this case.

In a similar vein, one may also recall the judgment L.E. $v$ Greece, ${ }^{42}$ adopted by the European Court in 2016. Even in this judgment, recourse to dignity was made with the aim of justifying the extension of Article 4 to a case of trafficking concerning a young Nigerian woman who had been forced into prostitution after entering Greek territory. ${ }^{43}$ Moreover, even in this case, dignity played the role of enabling the Court to extend Article 4 to factual situations which do not amount to ownership stricto sensu. ${ }^{44}$

Lastly, it is once again the need to protect the dignity of the applicants that was at stake in Chowdury $v$ Greece. ${ }^{45}$ By means of this important judgment, the European Court has got to the point of stating that in some cases 'exploitation through work' amounts to trafficking, being therefore covered by Article 4 of the Convention. ${ }^{46}$ For the sake of precision, in Chowdury the Court was dealing with some Bangladeshi migrants who were obliged to work without being paid in order to repay travel expenses, and also unable to move because of being

39 ibid para 54.

40 ibid paras $73-81$.

41 ibid para 54: 'There can be no doubt that trafficking and exploitation of prostitution threatens the buman dignity and fundamental freedoms of its victims and cannot be considered compatible with a democratic society and the values expounded in the Convention. In view of its obligation to interpret the Convention in the light of present-day conditions, the Court considers it unnecessary to identify whether the treatment of which the applicant complained constituted "slavery", "servitude" or "forced and compulsory labour". [...]' (italics added).

${ }^{42}$ L.E. $v$ Greece, App no 71545/12 (ECtHR, 21 January 2016).

${ }^{43}$ ibid para 58.

${ }^{44}$ As far as trafficking does not imply ownership 'stricto sensu over the victim.

${ }^{45}$ Chowdury and others v Greece, App no 21884/15 (ECtHR, 30 March 2017).

46 ibid para 93. 
irregular as well as deprived of their personal documents. ${ }^{47}$ Not only is dignity expressly referred to in this judgment, ${ }^{48}$ but also such a reference is all the more important, given that the above factual situation keeps repeating again and again in the relevant practice.

\section{Final remarks}

Summing up, one can easily conclude that dignity - or rather, respect for dignity - plays a very important role with regard to new slaveries understood as all those factual hypotheses in which individuals cannot be considered as property stricto sensu of an owner. Whether it is sexual slavery (Katanga, Kunarac) or servitude (Siliadin), serious exploitation of labour (Trabajadores de la Hacienda Brazil Verde) or trafficking of human beings (Rantsev, L.E. and Chowdury), dignity tends sometimes to be invoked for the purpose of making these hypotheses fall within the scope of application of existing international rules dealing with slavery or enslavement; ${ }^{49}$ other times, it tends to form part of the backdrop for such an interpretative activity. ${ }^{50}$

Insofar as recourse to dignity is intended for a similar purpose, it is worth repeating that this notion clearly plays the role of a general principle of human rights law, being also provided with the corresponding legal status. Furthermore, the case law at stake confirms that speaking of dignity is a concise way to refer to a minimum standard of treatment to be guaranteed to individuals placed under the power of public authorities or other private individuals.

The very fact that several international courts have had recourse to the principle of dignity in order to extend the above standard with respect to new forms of slavery is therefore to be commended. By means of dignity the said courts tend therefore to expand the 'hard core' of human rights, taking into account that the ban on slavery is an essential

${ }^{47}$ ibid paras 94-99.

48 ibid para 93.

${ }^{49}$ I refer to the judgments rendered by both the European and the Inter-American Court of Human Rights, respectively in Rantsev (n 17), Siliadin (n 16), S.M. (n 38), L.E (n 42), Chowdury (n 45) and Trabajadores de la Hacienda Brazil Verde (n 33 ).

${ }^{50} \mathrm{I}$ refer to the decisions adopted by the ICC and the ICTY, respectively in Katanga (n 23) and Kunarac (n 26). 
part of such a core. Against this, one could hardly invoke the extreme vagueness of a similar principle, if one only considers that vagueness is a normal feature of the category of general principles of law. 